\title{
Population genetics of lichen-forming fungi - a review
}

\author{
Silke WERTH
}

\begin{abstract}
Population genetics investigates the distribution of genetic variation in natural populations and the genetic differentiation among populations. Lichen-forming fungi are exciting subjects for population genetic studies due to their obligate symbiosis with a green-algal and/or cyanobacterial photobiont, and because their different reproductive strategies could influence fungal genetic structures in various ways. In this review, first, I briefly summarize the results from studies of chemotype variation in populations of lichen-forming fungi. Second, I compare and evaluate the DNA-based molecular tools available for population genetics of lichen-forming fungi. Third, I review the literature available on the genetic structure of lichen fungi to show general trends. I discuss some fascinating examples, and point out directions for future research.
\end{abstract}

Key words: genetic structure, genetic variation, lichenized ascomycetes, phylogeography, population

\section{Introduction}

Population genetics is an exciting field of enquiry in lichenology that has been promoted by DNA-based molecular markers. Exploring the pattern of genetic structure in natural populations of lichen-forming fungi and disentangling the processes that result in this pattern is crucial for our understanding of genetic variability in lichen populations. If used appropriately, population-genetic tools have the potential to reveal some highly interesting aspects of lichen biology such as dispersal and mating systems, which are not only of general interest per se, but might also have important implications for the conservation of endangered lichen-forming fungi.

Within the last two decades, DNA-based molecular taxonomy and phylogeny of lichen-forming fungi have become increasingly popular fields of study, whereas molecular studies at the population level are still far less common (DePriest 2004). For a few

S. Werth: Research Unit for Biodiversity and Conservation Biology, Swiss Federal Research Institute WSL, Zürcherstrasse 111, CH-8903 Birmensdorf, Switzerland;

Department of Ecology and Evolutionary Biology, University of California at Los Angeles, 621 Charles E Young Drive South, Los Angeles, California 900951606, USA. Email: silke.werth@wsl.ch lichen-forming fungal taxa, detailed studies of their genetic structure are readily available, and therefore two questions arise: do these studies show any general trends, and what can population genetics tell us about the biology of lichen fungi?

The purpose of this review is threefold: $i$ ) to summarize the knowledge gained in recent DNA-based population genetic research of lichen-forming fungi, ii) to evaluate the molecular tools available for the study of population genetics of lichen fungi, and iii) to point out interesting questions and directions for future research. This review does not deal with isozyme-based variation in lichen populations ( $c f$. Fahselt 2008).

\section{The genetic structure of lichen-forming fungi}

Molecular investigations of the genetic structure of lichen-forming fungi have the potential to reveal exciting aspects of their ecology and biology. The term 'genetic structure' refers to the quantity and distribution of genetic variation within and among populations and is an important property of natural populations as it might reflect the history of populations as well as their evolutionary potential (Excoffier 2007). Genetic structure 
results from four processes: mutation, drift, selection, and gene flow (Loveless \& Hamrick 1984). The genetic structure of populations reveals whether they have been isolated during an extended time period leading to genetic differentiation, and data on genetic structure can also determine the spatial scale at which populations are genetically differentiated. If they are not differentiated, one possible explanation is that gene flow might have been sufficiently high to prevent genetic differentiation among populations.

The genetic structure of populations may retain information essential for understanding population dynamics and relevant information for lichen conservation. Firstly, the genetic differentiation among populations and the distribution of genetic variation at various spatial scales tells us whether populations are isolated, or connected through gene flow, which has direct implications for conservation. Many lichens are threatened or endangered (Sérusiaux 1989; Tønsberg et al. 1996; Wirth et al. 1996; Thor 1998; Scheidegger et al. 2002), and a quantification of the genetic structure facilitates the development of efficient conservation strategies that take into account dispersal capability or genetic diversity (Moritz 1994, 2002). For instance, several rare or endangered lichens occupy geographically isolated habitats, and some epiphytic lichens have been reported to form patch-tracking metapopulations (Snäll et al. 2005; Wagner et al. 2006). The pattern of genetic differentiation among populations of such patch-tracking species allows us to evaluate their risk of extinction, and to suggest suitable strategies to preserve them (Zoller et al. 1999a; Werth et al. 2006b, 2007).

Secondly, detailed geostatistical analyses of the spatial clustering of genotypes within and among populations can reveal the spatial extent of clonal vs. sexual genetic structure, which in turn allows the ranges of clonal vs. sexual propagules to be inferred (Walser et al. 2004; Wagner et al. 2005; Werth et al. 2006b).

Thirdly, molecular phylogeography (see glossary, Appendix 1)(Avise et al. 1987) analyses the genetic structure of species on a range-wide scale, and can be used to infer population history (Printzen et al. 2003; Palice \& Printzen 2004; Buschbom 2007; Lücking et al. 2008), to localize refugia (Dépraz et al. 2008), and to identify migration routes (Hewitt 1996; Taberlet et al. 1998; Hewitt 1999, 2000).

\section{Literature base}

To summarize the major trends in early population studies of lichen-forming fungi, a literature search of the variation in fungal chemotypes at a population-level was performed. To find papers on chemotypic variation, the key words 'lichen' and 'chemotype' were used; subsequently papers that did not contain information on variation at the population level were removed. The literature search resulted in 16 papers on chemotypic variation in populations of lichen-forming fungi.

Then, a search was carried out for articles containing the key word: 'lichen' in combination with the following key words: 'population genetic', 'gene flow', 'genetic variation', and 'phylogeography' to build up a literature base of DNA-based populationgenetic studies of lichens; this yielded 35 papers. Publications that did not include classic population genetic data analysis, or at least measures of genetic diversity, were excluded, leaving 24 papers which are summarized in Table 2. For 12 studies, the genetic structure was quantified using either Analysis of Molecular Variance or $F$-statistics. These are discussed in detail below.

\section{Early population-level studies of chemotypic variation in lichen-forming fungi}

Possibly the earliest studies of within and among population variation in lichens were based on fungal secondary metabolites. In these, chemotypic variation was found to vary among conspecific individuals (Culberson 1986; Culberson et al. 1992). In fact, the first evidence of gene flow in lichens was achieved by the pioneering work of Chicita and William Culberson, who 
TABLE 1. Overview of the most commonly used DNA-based markers in population genetic studies of lichens and markers which might be of potential interest for future use (in parentheses). Cultures, sterile cultures of symbionts required; specific, markers are specific for one of the symbiosis partners

\begin{tabular}{|c|c|c|c|}
\hline Marker & Cultures & Specific & References \\
\hline RAPD & Yes & No & $\begin{array}{l}\text { (Murtagh et al. 1999; Printzen et al. 1999; Dyer et al. } \\
\text { 2001; Honegger et al. 2004a; Honegger et al. } 2004 b \text {; } \\
\text { Seymour et al. 2005a) }\end{array}$ \\
\hline AFLP & Yes & No & (Seymour et al. 2005a) \\
\hline PCR-RFLP & No & Yes & $\begin{array}{l}\text { (DePriest 1993; Beard \& DePriest 1996; Kroken \& } \\
\text { Taylor 2001b; Piercey-Normore \& DePriest 2001; } \\
\text { Piercey-Normore 2004) }\end{array}$ \\
\hline PCR-SSCP & No & Yes & (Kroken \& Taylor 2001a; Weising et al. 2005) \\
\hline Microsatellites & No & Yes & $\begin{array}{l}\text { (Walser et al. 2003; Walser 2004; Walser et al. 2004; } \\
\text { Wagner et al. 2005; Walser et al. 2005; Werth et al. } \\
2006 \text { a; Werth et al. 2006b; Werth et al. 2007) }\end{array}$ \\
\hline DNA sequence polymorphisms & No & Yes & $\begin{array}{l}\text { (Zoller et al. 1999a; Printzen \& Ekman 2003; Scherrer } \\
\text { \& Honegger 2003; Lindblom \& Ekman 2006; } \\
\text { Lindblom \& Ekman 2007; Werth \& Sork 2008) }\end{array}$ \\
\hline
\end{tabular}

observed that chemotypes differed between a thallus and its sporeling progeny grown in vitro (Culberson et al. 1988). The chemotypes of the sporeling progeny matched those of neighbouring adult thalli (Culberson et al. 1988; Culberson \& Culberson 1994). Based on chemotypic variation, gene flow was found to be common in some lichenized fungi (Culberson et al. 1988), whereas other mycobiont taxa appeared to be reproductively isolated (Culberson et al. 1993). Secondary metabolites of lichen-forming fungi have been reported to function as a light screen protecting the algal populations in a thallus (Gauslaa \& Solhaug 2001; Gauslaa \& McEvoy 2005), or to operate as metal chelators, water repelling agents, and deterrents against parasites (Stocker-Wörgötter et al. 2004). Chemotypic variation in lichens is therefore probably not to be considered as selectively neutral. Indeed, chemotypes of lichens are often found specific to a particular habitat (Hale 1956b; Culberson \& Culberson 1967; Culberson 1970; Culberson et al. 1977; Nash \& Zavada 1977), and a geographic structure closely resembling an ecocline has been found in several studies (Hale 1956a; Culberson \& Culberson 1982), indicating that chemotypes might respond to environmental gradients and might be under selection. However, one study has found a random distribution of chemotypes across a broad geographic range and within a very large sample (Hale 1963). The studies of the spatial distribution of chemotypes gave interesting insights into genetic variation within lichen populations. Unfortunately, the resolution of the studies of chemotypic variation in lichenized fungi is generally too low to allow for detailed population genetic analyses (Culberson \& Culberson 1994), which is why they were later replaced by studies employing other tools. Recent studies suggest that the concentration of secondary metabolites in lichen thalli may vary seasonally (Bjerke et al. 2005; Gauslaa \& McEvoy 2005), and changes with light intensity (Armaleo et al. 2008b).

\section{Techniques for recent DNA-based population genetic studies of lichenized fungi}

The following section, provides an overview of various molecular approaches and their utility for population genetics of lichenforming fungi, highlighting the questions for which different marker types are most suitable. The choice of a particular marker should be based on i) technical complexity of 
TABLE 2. Genetic structure in populations of lichen-forming fungi.

\begin{tabular}{|c|c|c|c|c|c|c|c|c|c|c|c|}
\hline Species & $\begin{array}{c}\text { Growth } \\
\text { form } \dagger\end{array}$ & Spatial scale & $\begin{array}{c}\text { Max. } \\
\text { distance } \\
\text { between } \\
\text { pops }(\mathrm{km})\end{array}$ & Locus $\ddagger$ & $\begin{array}{l}\text { No. } \\
\text { thalli }\end{array}$ & $\begin{array}{l}\text { Genetic dif- } \\
\text { ferentiation } \\
\left(\Phi_{\mathbf{S T}}\right)\end{array}$ & $\begin{array}{c}\text { Haplotype } \\
\text { diversity }\end{array}$ & $\begin{array}{c}\text { Mantel } \\
\text { cotrrelation } \\
\text { coefficient } \\
\left(r_{M}\right)\end{array}$ & $\begin{array}{l}\text { No. } \\
\text { polymor- } \\
\text { phic sites } \\
\text { (S) }\end{array}$ & $\begin{array}{c}\text { No. } \\
\text { haplo- } \\
\text { types }\end{array}$ & Reference \\
\hline \multirow[t]{2}{*}{$\begin{array}{l}\text { Cavernularia } \\
\text { hultenii }\end{array}$} & \multirow[t]{2}{*}{$\begin{array}{r}\text { Foliose } \\
\mathrm{V}(\mathrm{S})\end{array}$} & \multirow[t]{2}{*}{ Continents } & \multirow[t]{2}{*}{7800} & $\begin{array}{l}\mathrm{nr} \text { ITS, } \mathrm{nr} \\
\quad \text { IGS }\end{array}$ & 300 & - & - & - & 65 & 49 & Printzen et al. (2003) \\
\hline & & & & mtr LSU & 42 & - & - & - & 12 & 4 & $\begin{array}{l}\text { Printzen \& Ekman } \\
\quad(2002)\end{array}$ \\
\hline \multirow[t]{2}{*}{$\begin{array}{l}\text { Cladonia } \\
\quad \text { arbuscula }\end{array}$} & \multirow[t]{2}{*}{$\begin{array}{l}\text { Cladonioid } \\
\mathrm{V}(\mathrm{S})\end{array}$} & \multirow[t]{2}{*}{ Landscape } & 2 & $\begin{array}{l}\text { nr SSU } \\
\quad \text { intron flp }\end{array}$ & 50 & $0 \cdot 098^{\star \star ् ब ~}$ & - & - & - & 11 & $\begin{array}{l}\text { Robertson \& } \\
\text { Piercey-Normore } \\
\text { (2007) }\end{array}$ \\
\hline & & & 40 & $\begin{array}{l}\mathrm{nr} \text { SSU } \\
\quad \text { intron flp }\end{array}$ & 17 & - & - & - & - & 4 & $\begin{array}{l}\text { Piercey-Normore } \\
\quad(2006 b)\end{array}$ \\
\hline $\begin{array}{l}\text { Cladonia } \\
\text { chlorophaea }\end{array}$ & $\begin{array}{l}\text { Cladonioid } \\
\text { VS }\end{array}$ & Population & - & $\begin{array}{l}\mathrm{nr} \text { SSU } \\
\quad \text { intron flp }\end{array}$ & 11 & - & - & - & - & 9 & DePriest (1993) \\
\hline $\begin{array}{l}\text { Cladonia } \\
\text { gracilis }\end{array}$ & $\begin{array}{l}\text { Cladonioid } \\
\text { V(S) }\end{array}$ & Region & 500 & $\begin{array}{l}\mathrm{nr} \text { SSU } \\
\quad \text { intron flp }\end{array}$ & 50 & - & - & - & - & 4 & $\begin{array}{l}\text { Piercey-Normore } \\
\quad(2004)\end{array}$ \\
\hline $\begin{array}{l}\text { Cladonia } \\
\text { multiformis }\end{array}$ & $\begin{array}{l}\text { Cladonioid } \\
\mathrm{V}(\mathrm{S})\end{array}$ & Region & 500 & $\begin{array}{l}\mathrm{nr} \text { SSU } \\
\quad \text { intron flp }\end{array}$ & 36 & - & - & - & - & 3 & $\begin{array}{l}\text { Piercey-Normore } \\
\quad(2004)\end{array}$ \\
\hline $\begin{array}{l}\text { Cladonia } \\
\quad \text { rangiferina }\end{array}$ & $\begin{array}{l}\text { Cladonioid } \\
\text { V(S) }\end{array}$ & Region & 500 & $\begin{array}{l}\mathrm{nr} \text { SSU } \\
\quad \text { intron flp }\end{array}$ & 29 & - & - & - & - & 4 & $\begin{array}{l}\text { Piercey-Normore } \\
\quad(2004)\end{array}$ \\
\hline $\begin{array}{l}\text { Cladonia } \\
\text { subcervicornis }\end{array}$ & $\begin{array}{l}\text { Cladonioid } \\
\text { is VS }\end{array}$ & Landscape & 45 & $\mathrm{mt} \operatorname{COX} 1$ & 124 & - & - & - & 35 & 7 & $\begin{array}{l}\text { Printzen \& Ekman } \\
\quad(2003)\end{array}$ \\
\hline \multirow[t]{3}{*}{$\begin{array}{l}\text { Cladonia } \\
\text { subtenuis }\end{array}$} & \multirow[t]{3}{*}{$\begin{array}{l}\text { Cladonioid } \\
\text { VS }\end{array}$} & Region & 1200 & $\begin{array}{l}\mathrm{nr} \mathrm{SSU} \\
\text { intron }\end{array}$ & 44 & - & - & - & - & 3 & $\begin{array}{l}\text { Beard \& DePriest } \\
\quad(1996)\end{array}$ \\
\hline & & Region & 900 & $\mathrm{nr}$ ITS & 79 & $0 \cdot 092^{\star}$ & $0 \cdot 903$ & $-0.232^{\mathrm{ns}}$ & 112 & 32 & Yahr et al. 2006 \\
\hline & & & & EFA & 33 & - & - & - & 9 & 15 & \\
\hline $\begin{array}{l}\text { Cliostomum } \\
\text { corrugatum }\end{array}$ & Crustose S & Landscape & 80 & $\begin{array}{l}\text { nr SSU } \\
\quad \text { intron } \\
\text { sequence }\end{array}$ & & $0 \cdot 004^{\text {ns }}$ & - & ns & - & - & Lättman et al. (2009) \\
\hline $\begin{array}{l}\text { Evernia } \\
\quad \text { mesomorpha }\end{array}$ & $\begin{array}{c}\text { Fruticose } \\
\text { V(S) }\end{array}$ & Landscape & 12 & $\begin{array}{l}\mathrm{nr} \text { ITS } \\
\quad(\text { RFLP) }\end{array}$ & 290 & $0 \cdot 000^{\text {ns }}$ & - & - & 3 & 2 & $\begin{array}{l}\text { Piercey-Normore } \\
\quad(2006 a)\end{array}$ \\
\hline
\end{tabular}


TABLE 2. Continued

\begin{tabular}{|c|c|c|c|c|c|c|c|c|c|c|c|}
\hline Species & $\begin{array}{c}\text { Growth } \\
\text { form } \dagger\end{array}$ & Spatial scale & $\begin{array}{c}\text { Max. } \\
\text { distance } \\
\text { between } \\
\text { pops }(\mathrm{km})\end{array}$ & Locus $\ddagger$ & $\begin{array}{l}\text { No. } \\
\text { thalli }\end{array}$ & $\begin{array}{l}\text { Genetic dif- } \\
\text { ferentiation } \\
\left(\Phi_{\mathbf{S T}}\right)\end{array}$ & $\begin{array}{l}\text { Haplotype } \\
\text { diversity }\end{array}$ & $\begin{array}{c}\text { Mantel } \\
\text { cotrrelation } \\
\text { coefficient } \\
\left(r_{\mathrm{M}}\right)\end{array}$ & $\begin{array}{l}\text { No. } \\
\text { polymor- } \\
\text { phic sites } \\
\text { (S) }\end{array}$ & $\begin{array}{c}\text { No. } \\
\text { haplo- } \\
\text { types }\end{array}$ & Reference \\
\hline $\begin{array}{l}\text { Flavocetraria } \\
\text { nivalis }\end{array}$ & $\begin{array}{r}\text { Foliose } \\
\mathrm{V}(\mathrm{S})\end{array}$ & - & - & $\begin{array}{c}\text { nr ITS, nr } \\
\quad \text { IGS, mt } \\
\quad \text { LSU, } \\
\text { anony- } \\
\text { mous } \\
\quad \text { locus }\end{array}$ & 60 & - & - & - & 0 & 1 & $\begin{array}{l}\text { Opanowicz \& Grube } \\
\quad(2004)\end{array}$ \\
\hline $\begin{array}{l}\text { Hypogymnia } \\
\text { physodes }\end{array}$ & $\begin{array}{r}\text { Foliose } \\
\mathrm{V}(\mathrm{S})\end{array}$ & Region & 1000 & $\begin{array}{l}\text { SSU, ITS1, } \\
5.8 \mathrm{~S}, \\
\text { ITS } 2\end{array}$ & 104 & - & - & - & - & 15 & $\begin{array}{l}\text { Mattsson et al. } \\
\quad(2009)\end{array}$ \\
\hline $\begin{array}{l}\text { Hypogymnia } \\
\text { tubulosa }\end{array}$ & $\begin{array}{r}\text { Foliose } \\
\mathrm{V}(\mathrm{S})\end{array}$ & Region & & $\begin{array}{c}\text { SSU, ITS1, } \\
5.8 \mathrm{~S}, \\
\text { ITS2 }\end{array}$ & 16 & - & - & - & - & 7 & $\begin{array}{l}\text { Mattsson et al. } \\
\quad(2009)\end{array}$ \\
\hline \multirow[t]{7}{*}{$\begin{array}{l}\text { Letharia } \\
\quad \text { gracilis }\end{array}$} & \multirow[t]{7}{*}{$\begin{array}{l}\text { Fruticose } \\
\text { (V)S }\end{array}$} & \multirow[t]{7}{*}{ Region } & \multirow[t]{7}{*}{-} & nr ITS & 8 & - & - & - & 1 & 2 & \multirow[t]{7}{*}{$\begin{array}{l}\text { Kroken \& Taylor } \\
\quad(2001 b)\end{array}$} \\
\hline & & & & 11 (anon.) & 8 & - & - & - & 1 & 2 & \\
\hline & & & & 13 (anon.) & 8 & - & - & - & 3 & 2 & \\
\hline & & & & $\mathrm{DO}$ (anon.) & 8 & - & - & - & 1 & 2 & \\
\hline & & & & 14 (anon.) & 8 & - & - & - & 1 & 2 & \\
\hline & & & & CT (anon.) & 8 & - & - & - & 11 & 6 & \\
\hline & & & & BA (anon.) & 8 & - & - & - & 7 & 5 & \\
\hline \multirow[t]{6}{*}{$\begin{array}{l}\text { Letharia } \\
\quad \text { lupina }\end{array}$} & \multirow[t]{6}{*}{$\begin{array}{c}\text { Fruticose } \\
\text { V(S) }\end{array}$} & \multirow[t]{6}{*}{ Region } & \multirow[t]{6}{*}{ - } & 13 (anon.) & 9 & - & - & - & 1 & 2 & \multirow[t]{6}{*}{$\begin{array}{l}\text { Kroken \& Taylor } \\
\quad(2001 b)\end{array}$} \\
\hline & & & & BA (anon.) & 9 & - & - & - & 16 & 4 & \\
\hline & & & & 12 (anon.) & 9 & - & - & - & 3 & 2 & \\
\hline & & & & CHS1 & 9 & - & - & - & 1 & 2 & \\
\hline & & & & 4 (anon.) & 9 & - & - & - & 5 & 3 & \\
\hline & & & & CS (anon.) & 9 & - & - & - & 2 & 2 & \\
\hline \multirow[t]{2}{*}{$\begin{array}{l}\text { Letharia } \\
\quad \text { vulpina }\end{array}$} & \multirow[t]{2}{*}{$\begin{array}{l}\text { Fruticose } \\
\text { V(S) }\end{array}$} & \multirow[t]{2}{*}{ Continents } & \multirow[t]{2}{*}{ - } & nr SSU & 47 & - & - & - & 2 & 2 & \multirow[t]{2}{*}{$\begin{array}{l}\text { Högberg et al. } \\
\quad(2002)\end{array}$} \\
\hline & & & & CHS1 & 47 & - & - & - & 6 & 3 & \\
\hline
\end{tabular}


TABle 2. Continued

\begin{tabular}{|c|c|c|c|c|c|c|c|c|c|c|c|}
\hline Species & $\begin{array}{l}\text { Growth } \\
\text { form } \dagger\end{array}$ & Spatial scale & $\begin{array}{c}\text { Max. } \\
\text { distance } \\
\text { between } \\
\text { pops }(\mathrm{km})\end{array}$ & Locus $\ddagger$ & $\begin{array}{l}\text { No. } \\
\text { thalli }\end{array}$ & $\begin{array}{l}\text { Genetic dif- } \\
\text { ferentiation } \\
\quad\left(\Phi_{\mathbf{S T}}\right)\end{array}$ & $\begin{array}{l}\text { Haplotype } \\
\text { diversity }\end{array}$ & $\begin{array}{l}\text { Mantel } \\
\text { cotrrelation } \\
\text { coefficient } \\
\left(r_{M}\right)\end{array}$ & $\begin{array}{l}\text { No. } \\
\text { polymor- } \\
\text { phic sites } \\
\text { (S) }\end{array}$ & $\begin{array}{c}\text { No. } \\
\text { haplo- } \\
\text { types }\end{array}$ & Reference \\
\hline & & & & CT (anon.) & 47 & - & - & - & 13 & 3 & \\
\hline & & & & 12 (anon.) & 47 & - & - & - & 6 & 2 & \\
\hline & & & & 4 (anon.) & 47 & - & - & - & 2 & 2 & \\
\hline & & & & CS (anon.) & 47 & - & - & - & 12 & 3 & \\
\hline & & & & 13 (anon.) & 47 & - & - & - & 4 & 2 & \\
\hline & & & & BA (anon.) & 47 & - & - & - & 1 & 2 & \\
\hline \multirow{3}{*}{$\begin{array}{l}\text { Lobaria } \\
\text { pulmo- } \\
\text { naria }\end{array}$} & $\begin{array}{r}\text { Foliose } \\
\mathrm{V}(\mathrm{S})\end{array}$ & $\begin{array}{l}\text { Region } \\
\quad(\mathrm{CH}) »\end{array}$ & 250 & SSR & 122 & $0 \cdot 012^{\mathrm{ns}}$ & - & $-0 \cdot 4^{\mathrm{ns}} \rrbracket$ & - & - & Walser et al. (2005) \\
\hline & & $\begin{array}{l}\text { Region } \\
\text { (BC)» }\end{array}$ & 830 & SSR & 440 & $0.038^{\star}$ & $0 \cdot 53 ¥$ & - & - & - & \\
\hline & & Landscape & 3.7 & $\begin{array}{l}\text { SSR } \\
\quad \text { (LPu03, } \\
\text { LPu09, } \\
\text { LPu15) }\end{array}$ & 895 & $0 \cdot 544^{\star} €$ & $0 \cdot 27 ¥ €$ & $0 \cdot 05^{\star} €$ & - & - & $\begin{array}{l}\text { Werth et al. (2006b, } \\
\text { 2007) }\end{array}$ \\
\hline Porina alba & Crustose VS & Region & 200 & $\mathrm{mrSSU}$ & 50 & $0 \cdot 086^{\mathrm{ns}}$ & $0 \cdot 74$ & - & 34 & 13 & $\begin{array}{l}\text { Baloch \& Grube } \\
\quad(2009)\end{array}$ \\
\hline P. epiphylla & Crustose S & Region & 200 & $\mathrm{mrSSU}$ & 39 & $0 \cdot 147+$ & $0 \cdot 86$ & - & 60 & 13 & \\
\hline $\begin{array}{l}\text { P. karnatak- } \\
\text { ensis }\end{array}$ & Crustose S & Region & 200 & $\mathrm{mrSSU}$ & 35 & $0 \cdot 119+$ & $0 \cdot 85$ & - & 49 & 13 & \\
\hline P. lucida & Crustose S & Region & 200 & $\mathrm{mr} \mathrm{SSU}$ & 83 & $0.071+$ & $0 \cdot 81$ & - & 24 & 20 & \\
\hline $\begin{array}{l}\text { P. subepi- } \\
\text { phylla }\end{array}$ & Crustose S & Region & 200 & mr SSU & 23 & $0 \cdot 050^{\text {ns }}$ & $0 \cdot 92$ & - & 15 & 11 & \\
\hline \multirow{3}{*}{$\begin{array}{l}\text { Porpidia } \\
\text { flavi- } \\
\text { cunda }\end{array}$} & $\begin{array}{l}\text { Crustose } \\
\mathrm{S} / \mathrm{V}\end{array}$ & Continents & 4500 & BET & 96 & $0 \cdot 149^{\star}$ & $0 \cdot 88$ & $0 \cdot 40^{\mathrm{ns}}$ & - & 16 & Buschbom (2007) \\
\hline & & & & nr LSU & 110 & $0 \cdot 254^{\star}$ & $0 \cdot 83$ & $0 \cdot 43^{\mathrm{ns}}$ & - & 15 & \\
\hline & & & & RPB2 & 72 & $0 \cdot 386^{\star}$ & $0 \cdot 88$ & $0 \cdot 33^{\mathrm{ns}}$ & - & 13 & \\
\hline $\begin{array}{l}\text { Ramalina } \\
\text { menziesii }\end{array}$ & $\begin{array}{l}\text { Fruticose } \\
\text { (V)S }\end{array}$ & Landscape & 2 & $\begin{array}{r}\text { BET, gPD, } \\
\text { efa, UID }\end{array}$ & 72 & $0 \cdot 007^{\mathrm{ns}}$ & $\begin{array}{l}0.68 ¥, € \\
0.56 £, €\end{array}$ & $-0 \cdot 017^{\mathrm{ns}} €$ & - & - & $\begin{array}{l}\text { Werth \& Sork } \\
\text { (2008) }\end{array}$ \\
\hline
\end{tabular}


TABLE 2. Continued

\begin{tabular}{|c|c|c|c|c|c|c|c|c|c|c|c|}
\hline Species & $\begin{array}{l}\text { Growth } \\
\text { form } \dagger\end{array}$ & Spatial scale & $\begin{array}{c}\text { Max. } \\
\text { distance } \\
\text { between } \\
\text { pops }(\mathrm{km})\end{array}$ & Locus $\ddagger$ & $\begin{array}{l}\text { No. } \\
\text { thalli }\end{array}$ & $\begin{array}{l}\text { Genetic dif- } \\
\text { ferentiation } \\
\quad\left(\Phi_{\mathbf{S T}}\right)\end{array}$ & $\begin{array}{l}\text { Haplotype } \\
\text { diversity }\end{array}$ & $\begin{array}{c}\text { Mantel } \\
\text { cotrrelation } \\
\text { coefficient } \\
\left(r_{M}\right)\end{array}$ & $\begin{array}{l}\text { No. } \\
\text { polymor- } \\
\text { phic sites } \\
\text { (S) }\end{array}$ & $\begin{array}{c}\text { No. } \\
\text { haplo- } \\
\text { types }\end{array}$ & Reference \\
\hline $\begin{array}{c}\text { Thamnolia } \\
\text { subuli- } \\
\text { formis }\end{array}$ & $\begin{array}{l}\text { Cladonioid } \\
\text { V }\end{array}$ & Landscape & 4 & ISSR & 81 & $0 \cdot 173^{\star}$ & - & - & - & - & $\begin{array}{l}\text { Cassie \& Piercey- } \\
\quad \text { Normore (2008) }\end{array}$ \\
\hline $\begin{array}{l}\text { Trapeliopsis } \\
\quad \text { glaucolepi- } \\
\text { dea }\end{array}$ & Crustose VS & Continents & 9200 & nr ITS & 69 & $0 \cdot 276$ & $0 \cdot 73^{\mu}$ & - & 48 & 19 & $\begin{array}{l}\text { Palice \& Printzen } \\
\quad(2004)\end{array}$ \\
\hline \multirow[t]{4}{*}{$\begin{array}{l}\text { Xanthoria } \\
\text { parietina }\end{array}$} & Foliose S & Landscape & 25 & nr IGS & 226 & $0 \cdot 492^{\star}$ & $0 \cdot 78$ & ns & 11 & 12 & $\begin{array}{l}\text { Lindblom \& Ekman } \\
\quad(2007)\end{array}$ \\
\hline & & & 25 & nr ITS & 227 & $0.448^{\star}$ & 0.85 & $\mathrm{~ns}$ & 14 & 16 & \\
\hline & & & 3 & nr IGS & 213 & $0 \cdot 199^{\star}$ & $0 \cdot 70$ & ns & 14 & 10 & $\begin{array}{l}\text { Lindblom \& Ekman } \\
\quad(2006)\end{array}$ \\
\hline & & & 3 & nr ITS & 225 & $0.203^{\star}$ & $0 \cdot 75$ & ns & 19 & 16 & \\
\hline
\end{tabular}

${ }^{\dagger} \mathrm{S}$, sexual; $\mathrm{V}$, vegetative; $\mathrm{V}(\mathrm{S})$, predominantly vegetative dispersal; $\mathrm{S} / \mathrm{V}$, thalli either sexual or vegetative; -, no information available;

${ }^{\ddagger} \mathrm{mt}$, mitochondrial locus; $\mathrm{mtr}$, locus belonging to the mitochondrial ribosomal DNA cluster; nr, locus located within the nuclear ribosomal DNA cluster; LSU, large subunit; SSU, smal subunit; intron, intron polymorphism; flp, fragment length polymorphism; ITS, internal transcribed spacer; IGS, intergenic spacer; RPB2, RNA polymerase subunit 2; CHS1, chitin synthase 1; SSR, simple sequence repeat (microsatellite); COX1, cytochrome c oxidase, subunit 1; EFA, Elongation factor 1- $\alpha$; GPD, Glyceraldehyde 3-phosphate dehydrogenase; UID, an unidentified locus highly similar to glycine dehydrogenase;

" $0 \cdot 019^{\text {ns }}$ if multiple alleles were included.

$\checkmark$ Overall measure across continents

${ }^{\star} P \leq 0.05 ;+, 0.05<P<0 \cdot 1 ;$ ns, not significant at $P \leq 0.05$

" $\mathrm{CH}$, Switzerland; BC, British Columbia, Canada.

$\mu$, average

-, no test of statistical significance performed and $\Phi_{\mathrm{ST}}=0.0996$ if two haplotypes were removed.

$r_{\mathrm{M}}=0 \cdot 392^{\star}$ for samples $<500 \mathrm{~km}$, i.e., within $\mathrm{BC}$ and $\mathrm{CH}$.

$¥$ proportion of multilocus genotypes, calculated as $G / \mathrm{N}$ ( $G$, number of multilocus genotypes; $\mathrm{N}$, sample size)

$£$ Stoddart's genotypic diversity, a measure of evenness: $G_{0}=1 / \sum_{k} p_{i}^{2}$ (Stoddart \& Taylor 1988), standardized by dividing $G_{0}$ by the number of multilocus genotypes (k) following the suggestion of Kosman \& Leonard (2007).

$€ \mathrm{~S}$. Werth, unpublished data 
acquiring the data, ii) the quantity of variation a marker tends to yield, and iii) suitability of the genetic data for the analytical framework to be applied. In short, the simpler and the less time-consuming the data generation, and the higher the yield of genetic variability, the better. Possibly the most important criterion for marker choice is the suitability of the data for the kind of analysis to which it will be applied. Depending on the type of analysis, data from some types of markers might be much more preferable than others, and in some cases, one marker type may be the most suitable.

\section{Universal fingerprinting techniques}

Lichen thalli contain a lichenized fungus and at least one photobiont species. Frequently, endophytic bacteria, as well as endophytic and lichenicolous fungi may also be present in an individual lichen thallus. Therefore, DNA extracted from a lichen thallus will almost inevitably contain multiple species, which is one of the great technical challenges for population-genetic studies of lichens. Multiple species are usually present in lichen total genomic DNA extracts, which largely impedes the use of universal fingerprinting techniques such as Inter Simple Sequence Repeats (ISSR), Randomly Amplified Polymorphic DNA (RAPD), or Restriction Fragment Length Polymorphisms (RFLP), with which hundreds of thalli and multiple loci could be screened rather inexpensively. For a review of these fingerprinting techniques which are widely used in plants and animals, see Parker et al. (1998) and Weising et al. (2005). A fingerprinting technique that is currently widely used in plants and animals is Amplified Fragment Length Polymorphisms (AFLP), which have been reviewed by Meudt \& Clarke (2007) and Mueller \& Wolfensbarger (1999).

Fingerprinting techniques have to be used with extra precautions in lichenized fungi since PCR-based molecular assays are often highly sensitive, and can enable the detection of minute amounts of DNA (Werth et al. $2006 a$ ). Therefore, the presence of as little as a few cells of an undesired species in a DNA extract may contaminate a sample and lead to undesirable PCR fragments of the 'alien' species, which cannot usually be distinguished as such. To overcome this problem, the lichenized fungus can be isolated and fungal axenic cultures produced. From these pure sterile cultures, fungal DNA can be extracted which is suitable for universal fingerprinting techniques. Mycobiont isolates have recently been successfully used in combination with fingerprinting techniques to characterize lichen populations across their world distribution (Honegger et al. $2004 b$ ) and to make inferences on mating systems (Dyer et al. 2001; Honegger et al. 2004a; Seymour et al. 2005a, b). For lichenized fungi, Dyer et al. (2001) reviewed the use of RAPD fingerprinting and Murtagh et al. (1999) reported a RAPD protocol. A major drawback of universal fingerprinting is the requirement of having to work with pure axenic cultures since the establishment of sterile cultures for a large number of samples is very time-consuming and expensive. Also, a large number of mycobiont species cannot be grown in axenic culture. Thus, while very useful for some, isolates may not be the best approach for most lichen fungal species (Printzen \& Ekman 2003). Yet another drawback of universal fingerprinting methods is that they are dominant markers, which implies that the presence or absence of an allele is scored, but its inheritance usually remains obscure, and some population genetic analyses such as parentage analysis require co-dominant markers.

\section{Fungal-specific PCR-based markers}

PCR-based markers that are specific to the fungal partner of the symbiosis are an elegant solution to the technical problems that arise due to multispecies DNA extracts such as those of lichens (Zoller et al. 1999b; Printzen 2002; Printzen \& Ekman 2003; Walser et al. 2003). Owing to the availability of specific markers, the number of publicly available DNA sequences of the ribosomal gene cluster of lichenized fungi and their various photobiont partners has been increasing rapidly 
during the last decade. The most commonly used sequences in lichen phylogeny and population genetics today remain ribosomal DNA (rDNA) markers, namely the internal transcribed spacer (ITS), the intergenic spacer (IGS), the small subunit (SSU) and the large subunit (LSU). However, the multicopy rDNA gene cluster may exhibit little variability for population genetic studies of mycobionts (Zoller et al. 1999a; Opanowicz $\&$ Grube 2004). Several studies have furthermore pointed out the disadvantages of using multicopy DNA such as rDNA. Most importantly, multiple copies may exist due to failures of concerted evolution, a problem which does not exist at least in single copy genes. ITS paralogies are sometimes very clear-cut, easily detected and avoided (O'Donnell \& Cigelnik 1997; O'Donnell et al. 1998), but also more intriguing cases have been reported (Alvarez \& Wendel 2003). Another disadvantage is that the rDNA loci are physically linked and thus, sequences from multiple rDNA loci do not provide independent information. Also nuclear low copy or single copy genes may be problematic; they may not be variable enough to provide sufficient resolution for population genetic studies, and paralogs and pseudogenes may exist at least in low-copy genes. The best solution might be to use several independently inherited loci, for example, those from different organelles.

To amplify conserved parts of the nuclear genome, symbiont-specific primers can often be designed using even distantly related ascomycete species (Kroken \& Taylor 2000, 2001b; Högberg et al. 2002; Myllys et al. 2005). One problem may be that fungalspecific primers may occasionally amplify distantly related fungal taxa, if present in a thallus (e.g. lichenicolous fungi). In this case, new primers should be developed with improved specificity. Polymorphism in DNA sequences is most appropriate for studying range-wide genetic structure and large time scales (such as in phylogeographic investigations). DNA sequences are very well suited for any kind of analysis which assumes an evolutionary model (e.g., phylogenetic or coalescent-based analyses). In some cases, the amount of polymorphism in DNA sequences may be high enough to resolve even local genetic structure (Printzen \& Ekman 2003; Lindblom \& Ekman 2006; Werth \& Sork 2008).

Currently, full genome sequences are being generated for the lichen fungi Cladonia grayi (Armaleo et al. 2008a) and Xanthoria parietina (P. S. Dyer, personal communication). In future, lichenologists will be able to explore the full wealth of information in these genomes for designing new markers. Also, very exciting and entirely different questions may be asked that highlight the nature of gene expression among partners of the symbiosis (Joneson et al. 2008; McDonald et al. 2008). With entire genomes at hand for lichen-forming fungi, it will also be possible one day to study various aspects of adaptive genetic variation, a topic increasingly receiving attention in animals and higher plants, and even in non-model organisms (Vasemägi et al. 2005; Jump et al. 2006; Joost et al. 2007a, b). Hopefully, the ecological genomics of lichen-forming fungi, and adaptations of lichens relative to global climate will receive some attention in future studies.

\section{Simple sequence repeat (SSR) markers}

The seemingly most promising markers for population genetics of lichenized fungi are simple sequence repeats (i.e., microsatellites and minisatellites), as they are highly polymorphic. Primers can be designed specific to one symbiont, and SSR can thus be used on whole lichen thallus DNA extracts. SSR markers have not yet been developed for a wide range of lichen-forming fungi (but see Walser et al. 2003). The first studies using SSR markers in lichens revealed high levels of intrapopulational polymorphism where sequences from rDNA had detected little. For instance, based on sequencing of the nuclear ribosomal ITS and LSU regions, six haplotypes were found among 81 thalli of Lobaria pulmonaria collected from six populations that were located at distances of $50-250 \mathrm{~km}$ from each other within Switzerland (Zoller et al. 1999a). A recent study using SSR detected 176 multilocus genotypes among 895 
thalli of L. pulmonaria collected at distances up to $3.7 \mathrm{~km}$. Even recently disturbed sites exhibited relatively high levels of genetic diversity (Werth et al. 2006b). A major drawback of SSR markers is that they may not necessarily be applicable to other species, though closely related species may be crossamplified successfully (S. Werth, unpublished data; Walser et al. 2003). Often, less genetic variability is found in the species for which the marker was not originally developed. This implies that in order to be able to work with new taxa, usually new SSR markers have to be developed, and marker development and testing are expensive and time-consuming. However, once new markers have been developed, genotyping is inexpensive (Jarne \& Lagoda 1996).

The questions that can be answered using SSR include the typical hierarchical model of genetic structure-type questions ("at which hierarchical level do we observe structure?"). However, more complex issues such as paternity of spores, sporelings and juveniles, could also be addressed thanks to the high within-population diversity that these markers typically reveal.

Owing to the high degree of homoplasy if long time-scales are considered, in particular in cases where mutation is higher than migration, the length polymorphism in SSR loci is often not suitable, e.g. for studying rangewide genetic structure or for inferring genealogies (Ellegren 2000; Zhang \& Hewitt 2003). Moreover, if an evolutionary model should be applied to answer a particular question, DNA (or protein) sequences may be far more suitable than SSR (Dettman \& Taylor 2004). Examples of analytical frameworks which apply evolutionary models include phylogenetics or the coalescent. In some cases, microsatellite markers, too, may be used successfully for such applications, for instance when combined with SNP markers (Hey et al. 2004).

\section{Some important basic questions}

Some basic questions that may be asked in future population genetic studies of lichen- forming fungi are suggested here. It is certainly well beyond the scope of single projects to tackle all of these simultaneously. However, lichenologists starting up research projects on previously unstudied fungal taxa might consider focusing on a small selection of these questions. It is important to bear in mind that some species might be more suitable for certain questions than others. Answering the first two questions would establish baseline data on the genetic structure of mycobiont populations. Below, I arbitrarily consider a 'landscape' as an area of $1-50$ square $\mathrm{km}$, with $10 \mathrm{~km}$ as the largest distance among populations. Any larger area or any sampling area including larger maximum distances, I refer to as a 'region'.

i) What is the spatial scale where mating is random, i.e., at which spatial scale can we delimit populations? For instance, populations might be large and continuous with no genetic structure, as recently documented in Ramalina menziesii sampled in a landscape of a few square $\mathrm{km}$ (Werth \& Sork 2008). Other species might show metapopulation systems with high differentiation among neighbouring patches, but no genetic differentiation at larger spatial scales. This kind of structure would be typical of patch-tracking species, for example, Lobaria pulmonaria tracking its phorophytes in the Swiss Jura (Werth et al. 2007). Extremely rare species with small local population sizes should show high differentiation among populations both at small and at large spatial scales; this pattern yet remains to be demonstrated for lichenforming fungi.

ii) How is the genetic variation distributed across various spatial scales (e.g. region, landscape, population)? This question is a variation of the first question and may provide important insights into the distribution of genetic variance in lichen-forming fungi, in particular at large spatial scales. For instance, one might choose to study genetic differentiation among populations of a fungal species on different continents (Buschbom 2007), or of populations belonging to different geographical or ecoregions (e.g., Walser et al. 2005; Baloch \& Grube 2009), or the pattern of genetic differentiation among 
populations sampled from across landscapes (e.g. Lindblom \& Ekman 2007; Werth et al. 2007; Werth \& Sork 2008).

iii) Are there any geographic features which correspond to major breaks in gene flow? This question provides information about major physical barriers precluding genetic exchange among populations, and might be the most relevant for landscape-scale studies that investigate a large number of populations. For instance, Werth et al. (2007) found that a large pasture did not represent a barrier to gene flow in L. pulmonaria. Similarly, it would be interesting to find out if a landscape 'matrix' consisting of unforested land (e.g. clearcuts) or settlements might represent a barrier to gene flow in dispersal-limited old forest species, or whether land areas act as barriers for aquatic lichen fungi.

iv) How does the fungal mating system (e.g., clonal vs. sexual; homothallic vs. heterothallic) influence genetic structure? Fairly little is known about the mating system in lichens, even though in the past years, the mating systems of a few species have been determined. For instance, a homothallic mating system has been demonstrated for Xanthoria parietina (Honegger et al. 2004a; Scherrer et al. 2005), Graphis scripta, and Ochrolechia parella (Murtagh et al. 2000; Dyer et al. 2001), while 25 other fungal species were heterothallic, five of these belonging to the genus Xanthoria (Honegger et al. 2004a; Scherrer et al. 2005; Seymour et al. 2005a; Honegger \& Zippler 2007). The heterothallic species included rare or declining species as well as several that were common and widespread (Honegger \& Zippler 2007). It would be interesting to compare the genetic structures of congeneric homothallic and heterothallic fungal species. A heterothallic, obligate outcrosser should, in principle, exhibit more genetic variability within populations than a homothallic species as each sexual reproductive event may generate new genotypes. In contrast, a homothallic species should often perpetuate the same genotype when reproducing sexually. The effect of these mating systems on genetic structure should depend largely on the dispersal range of ascospores, as well as the frequency of sexual vs. clonal propagation. Assuming a relatively large ascospore dispersal range and that species are exclusively sexual, this might translate to less genetic structure in homothallic species, as the repeated occurrences of the same genotypes should homogenize the genetic differences among populations. No studies have, as yet, compared the genetic structures of species with different breeding systems. It would be mandatory that any such studies carried out the comparisons on material from the same geographic region, and at best even from the same landscape and from the same substrata, so that other influential factors could largely be excluded.

v) Do species which differ in their reproductive modes (e.g. sexual vs. asexual) or dispersal syndromes (e.g. soredia vs. isidia) show different trends in their genetic structure? The effect of sexual vs. asexual reproductive systems and of different dispersal syndromes on genetic structure remains largely unexplored. Also here, the effect on genetic structure depends on the dispersal range of propagules. For instance, species dispersing with large, vegetative propagules (e.g. isidia or thallus fragments) should be expected to exhibit more genetic structure relative to those with smaller propagules (e.g. soredia) which should disperse over larger distances. Secondly, sexual propagules are assumed to disperse over larger distances than asexual propagules, which would tend to homogenize genetic structures. Overall, the effect should depend on the relative frequency of sexuality/clonality and the frequency of the larger and smaller propagule types. Much more research is needed to determine whether the above predictions on genetic structure indeed hold true in natural populations. Sympatric species differing in dispersal syndrome or reproductive mode (clonal/sexual) should be investigated in the same study area and sites.

\section{DNA-based population genetic studies of lichen-forming fungi}

To facilitate comparability, I have suggested some statistics that could be included in future population genetic studies of 
lichen-forming fungi (Appendix 2). The genetic variation found in populations of lichen fungi is summarized in Table 2 . So far, population genetic investigations of lichenforming fungi have focused mainly on macrolichens, e.g. foliose and fruticose lichens. Moreover, only a limited number of mycobiont species have been investigated with population genetic methods. Little is known about the population genetic structure of crustose lichen fungi (but see Buschbom 2007; Lättman et al. 2009), and to the best of my knowledge, no studies of population genetic structure have yet been performed on leprose lichen fungi. Some species of lichens exhibit high genetic variability in populations, as seen in haplotype numbers (e.g., Cladonia arbuscula, C. chlorophaea, Ramalina menziesii) and nucleotide diversity (e.g. Porpidia flavicunda). There appears to be no clear pattern of genetic diversity relative to the functional group, or the reproductive mode of the lichen-forming fungal species, which might be partly due to the differences and in the spatial scale of the sampling (Table 2).

\section{Genetic structure of lichen-forming fungi}

The results of studies dealing with the genetic structure of populations of lichenforming fungi are summarized in Table 2 . It is not unproblematic to compare the genetic structure across studies, as different markers were utilized, the spatial scale varies among studies, different taxonomic groups were included, and the study species have a different life history (e.g. mating system, generation time). These factors alone might lead to different results among studies. Nevertheless, the ten studies reporting genetic structure show one surprising result. When comparing the studies performed at the landscape scale at approximately the same distance, genetic differentiation $\left(\Phi_{\mathrm{ST}}\right)$ among populations of foliose lichen species (Xanthoria parietina, Lobaria pulmonaria) was about two orders of magnitude higher than that of the two fruticose species (Evernia mesomorpha, Ramalina menziesii), whereas the value for the only cladonioid species included was slightly lower, but still close to those of the foliose species. More studies need to be performed to see whether this pattern is spurious or if it holds true as new species are included.

There is no obvious trend regarding the predominant reproductive mode of the species and their pattern of genetic differentiation; for instance, the range of $\Phi_{\mathrm{ST}}$ values for predominantly sexual species was roughly two orders of magnitude, and the same was true for predominantly asexual species (Table 2). However, this might be due to the individual properties of the species considered, as well as their wide taxonomic range. Future studies to answer this question could investigate the genetic structure of sympatric congeners with different dispersal syndromes (e.g., sexual vs. asexual/isidia vs. asexual/ soredia) in the same locations.

As one would expect, the two studies at the intercontinental scale show rather high genetic differentiation among populations (Table 2). Also, genetic differentiation increases with geographic distance in Xanthoria parietina, which is a typical situation when there is isolation by distance. A finding which might seem contra-intuitive at first is that in Lobaria pulmonaria, genetic differentiation decreases as the geographic scale of sampling increases (i.e., 'identity by distance', rather than isolation). However, the high values of differentiation among populations within the landscape are characteristic for a species which forms patch-tracking metapopulations. In this case, owing to the colonization/ extinction dynamics, the multilocus genotypes of adjacent populations may be highly dissimilar, while the same alleles might show up over and over again as the scale of sampling increases, implying little differentiation at large spatial scales. After these remarks on general trends and patterns in the underlying studies, some aspects of them are highlighted below.

Landscape scale. Significant genetic differentiation was found among populations of the terricolous lichen Cladonia arbuscula located within a Canadian landscape, a species which disperses with thallus fragments and 
does not form other vegetative propagules (Robertson \& Piercey-Normore 2007). This study was based on group I-like introns in the nuclear ribosomal short subunit (SSU).

Populations of the fruticose epiphytic lichen Evernia mesomorpha, a species dispersing mainly vegetatively with soredia, exhibited no significant population subdivision within a landscape of eastern Canada (Piercey-Normore 2006a). The study made use of PCR-RFLP of a nuclear ribosomal gene and detected two haplotypes.

Using sequences of two nuclear ribosomal loci, Lindblom \& Ekman $(2006,2007)$ found significant genetic differentiation among populations of Xanthoria parietina within two landscapes. Saxicolous and epiphytic populations were differentiated, as well as populations from the same habitat type (Lindblom \& Ekman 2006, 2007). Printzen \& Ekman (2003) found significant genetic differentiation among several island populations of $\mathrm{Cla}$ donia subcervicornis based on DNA sequences of a mitochondrial intron.

Populations of Lobaria pulmonaria located at short distances from each other in a pasture-woodland landscape were significantly differentiated when investigated with nuclear SSR markers (Werth et al. 2007). The genetic diversity of populations in the investigated pasture-woodland landscape strongly depended on the type of disturbance (Werth et al. 2006b).

In the epiphytic lichen Ramalina menziesii, Werth \& Sork (2008) found no significant differentiation among populations collected from four sites and three phorophyte species in a southern Californian landscape, indicating high gene flow at the landscape scale. They used DNA sequence polymorphisms of four nuclear loci.

Regional scale. Printzen et al. (1999) investigated the genetic structure of the crustose lichen Biatora helvola across its range in Europe using RAPD fingerprintings of fungal apothecial tissue. They found that samples from different areas were genetically distinct. The areas of distinctness corresponded to geographically isolated subranges of Norway spruce, a phorophyte of B. helvola.
Significant genetic differentiation was found among populations of Lobaria pulmonaria within a large geographic region (British Columbia) investigated with nuclear SSR, whereas three Swiss populations were not differentiated (Walser et al. 2005). Walser et al. (2005) suggested that the regional pattern of differentiation found in British Columbia was related to different glacial and postglacial histories of coastal and inland populations.

Tropical Latin-American and temperate European populations of the crustose lichen Trapeliopsis glaucolepidea shared no haplotypes in a nuclear ribosomal locus, and genetic differentiation among populations from different continents was high (Palice \& Printzen 2004). Palice \& Printzen (2004) interpreted this pattern as evidence against recurrent gene flow between continents. Moreover, they found high levels of genetic differentiation among populations within each continent.

Investigating populations of the boreal and arctic lichen Porpidia flavicunda in Europe and North America using two nuclear low copy genes as well as a nuclear ribosomal gene, Buschbom (2007) found significant genetic differentiation between regions, while there was no differentiation among populations within each region. Gene flow in the species was found to be asymmetric among sites, indicating high gene flow from Greenland into Europe, and higher gene flow from Greenland and continental Canada into Baffin Island than vice versa.

Honegger et al. (2004b) investigated worldwide samples of populations of Xanthoria parietina using RAPD fingerprints run on DNA isolated from fungal axenic cultures. They found two main clades, one restricted to the Iberian Peninsula, the Canary and the Balearic Islands, and a second clade containing all other isolates including those from Europe, North America and the southern Hemisphere. Interestingly, the genetic similarity of samples from Australia and New Zealand to those from Europe suggested that the lichen may have been introduced in the Southern Hemisphere by human action. 
Printzen et al. (2003) conducted a rangewide phylogeographic study on the epiphytic lichen Cavernularia hultenii, based on DNA sequences of two nuclear ribosomal loci. They found genetic evidence for one southern and at least one northern glacial refugium in South Central Alaska. Genetic drift was inferred to be the process that had created the phylogeographic structure, and there was no evidence of recent intercontinental dispersal (Printzen et al. 2003).

Högberg et al. (2002) found lower genetic variability in three European than in one Californian population of Letharia vulpina when using DNA sequences of eight fungal loci . They interpreted the lower variability of European populations as evidence that the European populations had been founded by recent intercontinental dispersal from North America (Högberg et al. 2002). However, due the low sample size employed in the study on Letharia vulpina, the data have to be interpreted with caution. Alternatively, the observed differences in genetic variability could also be due to the differing postglacial histories of Europe and western North America (as in the lichen-forming fungus investigated by Printzen et al. 2003). Most European taxa experienced severe genetic bottlenecks due to oscillations in Pleistocene climate (Taberlet et al. 1998; Hewitt 1999, 2000). In some areas of Europe, genetic variation may thus be low, whereas in other areas, recolonizing lineages meet and genetic diversity is very high ("suture zones"). In contrast, California was not affected by the Pleistocene climate fluctuations in the same way as Europe. For instance, most of California was not glaciated during the Pleistocene glacial and interglacial cycles. Accordingly, a recent phylogeographic study found much higher genetic variation in Californian than in European populations of white oaks, pointing towards California acting as a regional refugial area (Grivet et al. 2006). Therefore, for European Letharia vulpina, at least one alternative hypothesis other than recent intercontinental dispersal seems plausible; old populations in Europe may have gone through profound genetic bottlenecks during the Pleistocene climatic oscillations, leading to their genetic depauperation. Further investigations with a more exhaustive sampling effort would be necessary to clarify this interesting issue.

\section{Spatial genetic structure of lichen populations}

The only lichen fungus whose spatial genetic structure has been investigated in much detail is Lobaria pulmonaria. Walser et al. (2005) found significant spatial genetic structure in L. pulmonaria at distances below $500 \mathrm{~km}$ (i.e., within regions).

Using variograms, my co-workers and I found significant spatial autocorrelation in genotype diversity and gene diversity of $L$. pulmonaria (Wagner et al. 2005, Werth et al. 2006b). Interestingly, the spatial extent of clonal structure differed between forest stands that had been subjected to different types of disturbances (Werth et al. 2006b). For example, a fire-disturbed area had the largest extent of clonal structure, and we suggested that this area may have been recolonized through a few immigration events followed by substantial clonal propagation (Werth et al. $2006 b$ ). The spatial genetic structure found was predominantly due to clonality. When the effect of clonality had been removed, no significant spatial autocorrelation remained, indicating random dispersal of sexual propagules.

Confirming our results, Walser et al. (2004) found significant clonal spatial structure in three Swiss populations of L. pulmonaria. As no significant spatial autocorrelation remained once recurrent multilocus genotypes had been removed, the spatial genetic structure was mainly attributable to clonality. However, the spatial genetic structure was different in L. pulmonaria collected from British Columbia, where no significant spatial autocorrelation was detected at any scale, a pattern which they interpreted as evidence for frequent outcrossing (Walser et al. 2004).

\section{Molecular ecology of lichens}

\section{Lichen dispersal: "the answer is blowin' in the wind"}

There are three ways of studying dispersal, direct and indirect studies of dispersal, and 
simulation studies (Scheidegger \& Werth 2010). Direct approaches to dispersal, be they molecular or not, strive to detect propagules directly, for example, in environmental samples taken at a known distance from a potential source. Where possible, propagules are identified morphologically (Bailey \& James 1979; Armstrong 1987, 1990, 1994; Heinken 1999; Lorentsson \& Mattsson 1999), or identification is undertaken by using a molecular detection method (e.g. Walser et al. 2001; Werth et al. 2006a). Direct dispersal studies of lichens have been facilitated greatly by the availability of molecular markers. PCR-based detection methods may enable the direct detection of as little as a single propagule (Walser et al. 2001), as well as the discrimination among different propagule haplotypes (Werth et al. 2006a). Walser et al. (2001) detected propagules of $L$. pulmonaria at distances of up to $50 \mathrm{~m}$ from a source tree. Species-specific markers allowed recognition of single propagules of $L$. pulmonaria in a landscape and to distinguish locally dispersed diaspores from propagules that had been dispersed over a larger distance (Werth et al. 2006a). These direct dispersal data showed that many propagules of $L$. pulmonaria were dispersed locally, but that also dispersal over longer distances ( $\geq 200 \mathrm{~m}$ ) was much more common than previously anticipated (Werth et al. $2006 a$ ). In addition, it was demonstrated that establishment rates in L. pulmonaria are low (Werth et al. 2006a). Thus establishment, rather than dispersal, appears to be the limiting factor in the life history of $L$. pulmonaria.

In contrast, the indirect approaches to quantifying dispersal make use of genotypic data on populations, which are interpreted in terms of dispersal. For instance, the probability that an individual has dispersed from another population can be calculated using assignment tests (Pritchard et al. 2000; Paetkau et al. 2004). In an indirect approach to dispersal, Walser (2004) investigated the genetic variation within a cohort of juvenile thalli of L. pulmonaria on a tree trunk and found little genetic variation (three multilocus genotypes in 30 samples, the most fre- quent one found 27 times). He also studied the variation in adult thalli along a $200 \mathrm{~m}$ transect, finding a spatial clustering of multilocus genotypes. Based on the genotypes, he concluded that dispersal in L. pulmonaria was spatially restricted. However, it is important to note that indirect dispersal estimates based on established thalli generally underestimate dispersal, because they do not take into account the fraction of dispersed diaspores that died during establishment (Werth et al. 2006a).

A recent simulation study confirmed the results on the dispersal of propagules found by Werth et al. (2006a), showing that a scenario of local dispersal with a substantial amount of long distance dispersal was appropriate to describe the genetic structure found in the studied landscape (Wagner et al. 2006).

One interesting question is whether 'asexual species' indeed disperse exclusively by asexual propagation. Nelsen \& Gargas (2008) recently investigated the congruence of photobiont and mycobiont phylogenies in several species belonging to the leprose and putatively exclusively asexual genus Lepraria. The leprose fungal species had previously been assumed to be strictly asexual, which would imply a strictly vertical transmission mode of photobionts. Instead, Nelsen and Gargas (2008) found that identical algae associated with multiple fungal species, and that phylogenies were not strictly congruent, supporting algal switching among fungi and horizontal transmission of photobionts.

Another interesting study provided insight on the dispersal mode of a fungus by studying codispersal of mycobiont and photobiont. In Cladonia subtenuis, a species which does not produce any vegetative, symbiotic propagules, the same symbiotic genotype was repeatedly found, both within and among populations, which was hypothesized to be due either to vegetative dispersal, or to widespread dispersal and relichenization in this fungus (Yahr et al. 2006). Moreover, Yahr et al. (2006) found the same fungal genotype in association with different algal genotypes, demonstrating horizontal transfer of photobionts in this species. 
While all the above examples have given a first hint at the dispersal biology of lichens, it needs to be kept in mind that all these studies have focused on a few species only, and for many other species, such information regarding their dispersal pattern has still to be gathered. It would be particularly interesting to investigate the dispersal ability of lichen fungi differing markedly in dispersal syndrome and reproductive mode from $L$. pulmonaria; for instance, purely asexual or exclusively sexual species.

\section{Conclusion}

Here, I have reviewed the population genetic structure of lichen-forming fungi. Lichenology has benefited substantially from the recent development of DNA based molecular tools and their application at the population level. There are many fascinating biological insights still to be gained from the study of lichen fungi through molecular tools. In fact, many exciting questions will remain unanswered if one chooses to focus solely on traditional methods. An integration of molecular and traditional approaches will help to better understand the interesting biology of lichens, and it holds the potential to reveal some as of yet largely unexplored aspects such as dispersal patterns, mating patterns and parentage in lichen populations.

This research was funded by the Swiss National Foundation (PBBEA-111207, 3100AO-105830 and 31003A_1276346/1). I thank Gernot Segelbacher, Rebecca Yahr and two anonymous reviewers for valuable comments on an earlier draft of the present manuscript.

\section{REFERENCES}

Alvarez, I. \& Wendel, J. F. (2003) Ribosomal ITS sequences and plant phylogenetic inference. Molecular Phylogenetics and Evolution 29: 417-434.

Armaleo, D., Zhang, Y. \& Cheung, S. (2008b) Light might regulate divergently depside and depsidone accumulation in the lichen Parmotrema hypotropum by affecting thallus temperature and water potential. Mycologia 100: 565-576.

Armstrong, R. A. (1987) Dispersal in a population of the lichen Hypogymnia physodes. Environmental and Experimental Botany 27: 357-363.

Armstrong, R. A. (1990) Dispersal, establishment and survival of soredia and fragments of the lichen
Hypogymnia physodes (L) Nyl. New Phytologist 114: 239-245.

Armstrong, R. A. (1994) Dispersal of soredia from individual soralia of the lichen Hypogymnia physodes (L.) Nyl. in a simple wind tunnel. Environmental and Experimental Botany 34: 39-45.

Avise, J. C., Arnold, J., Ball, R. M., Bermingham, E., Lamb, T., Neigel, J. E., Reeb, C. A. \& Saunders, N. C. (1987) Intraspecific phylogeography - the mitochondrial-DNA bridge between population genetics and systematics. Annual Review of Ecology and Systematics 18: 489-522.

Bailey, R. \& James, P. (1979) Birds and the dispersal of lichen propagules. Lichenologist 11: 105-106.

Baloch, E. \& Grube, M. (2009) Pronounced genetic diversity in tropical epiphyllous lichen fungi. Molecular Ecology 18: 2185-2197.

Beard, K. H. \& DePriest, P. T. (1996) Genetic variation within and among mats of the reindeer lichen Cladina subtenuis. Lichenologist 28: 171-181.

Bjerke, J. W., Elvebakk, A., Dominguez, B. \& Dahlback, A. (2005) Seasonal trends in usnic acid concentrations of arctic, alpine and Patagonian populations of the lichen Flavocetraria nivalis. Phytochemistry 66: 337-344.

Buschbom, J. (2007) Migration between continents: geographical structure and long-distance gene flow in Porpidia flavicunda (lichen-forming Ascomycota). Molecular Ecology 16: 1835-1846.

Cassie, D. M. \& Piercey-Normore, M. D. (2008) Dispersal in a sterile lichen-forming fungus, Thamnolia subuliformis (Ascomycotina: Icmadophilaceae). Botany-Botanique 86: 751-762.

Culberson, C. F., Culberson, W. L. \& Johnson, A. (1988) Gene flow in lichens. American fournal of Botany 75: 1135-1139.

Culberson, C. F., Culberson, W. L. \& Johnson, A. (1992) Characteristic lichen products in cultures of chemotypes of the Ramalina siliquosa complex. Mycologia 84: 705-714.

Culberson, W. L. (1970) Chemosystematics and ecology of lichen-forming fungi. Annual Review of Ecology and Systematics 1: 153-170.

Culberson, W. L. (1986) Chemistry and sibling speciation in the lichen-forming fungi: ecological and biological considerations. Bryologist 89: 123-131.

Culberson, W. L. \& Culberson, C. F. (1967) Habitat selection by chemically differentiated races of lichens. Science 158: 1195-1197.

Culberson, W. L. \& Culberson, C. F. (1982) Evolutionary modification of ecology in a common lichen species. Systematic Botany 7: 158-169.

Culberson, W. L. \& Culberson, C. F. (1994) Secondary metabolites as a tool in ascomycete systematics: lichenized fungi. In Ascomycete Systematics: Problems and Perspectives in the Nineties (D. L. Hawksworth, ed.): 155-163. New York: Plenum Press.

Culberson, W. L., Culberson, C. F. \& Johnson, A. (1977) Correlations between secondary-product chemistry and ecogeography in the Ramalina siliquosa group (lichens). Plant Systematics and Evolution 127: 191-200. 
Culberson, W. L., Culberson, C. F. \& Johnson, A. (1993) Speciation in lichens of the Ramalina siliquosa complex (Ascomycotina, Ramalinaceae): gene flow and reproductive isolation. American fournal of Botany 80: 1472-1481.

Dépraz, A., Cordellier, M., Hausser, J. \& Pfenninger, M. (2008) Postglacial recolonization at a snail's pace (Trochulus villosus): confronting competing refugia hypotheses using model selection. Molecular Ecology 17: 2449-2462.

DePriest, P. T. (1993) Small subunit rDNA variation in a population of lichen fungi due to optional group-I introns. Gene 134: 67-74.

DePriest, P. T. (2004) Early molecular investigations of lichen-forming symbionts: 1986-2001. Annual Review of Microbiology 58: 273-301.

Dettman, J. R. \& Taylor, J. W. (2004) Mutation and evolution of microsatellite loci in Neurospora. Genetics 168: 1231-1248.

Dyer, P. S., Murtagh, G. J. \& Crittenden, P. D. (2001) Use of RAPD-PCR DNA fingerprinting and vegetative incompatibility tests to investigate genetic variation within lichen-forming fungi. Symbiosis 31: 213-229.

Ellegren, H. (2000) Microsatellite mutations in the germline: implications for evolutionary inference. Trends in Genetics 16: 551-558.

Excoffier, L. (2007) Analysis of population subdivision. In Handbook of Statistical Genetics (D. J. Balding, M. Bishop \& C. Cannings, eds.): 980-1020. Chichester, UK: Wiley.

Fahselt, D. (2008) Individuals and populations of lichens. In Lichen Biology (T. H. Nash, ed.): 252-273. Cambridge: Cambridge University Press.

Gauslaa, Y. \& McEvoy, M. (2005) Seasonal changes in solar radiation drive acclimation of the sunscreening compound parietin in the lichen Xanthoria parietina. Basic and Applied Ecology 6: 75-82.

Gauslaa, Y. \& Solhaug, K. A. (2001) Fungal melanins as a sun screen for symbiotic green algae in the lichen Lobaria pulmonaria. Oecologia 126: 462-471.

Grivet, D., Deguilloux, M. F., Petit, R. J. \& Sork, V. L. (2006) Contrasting patterns of historical colonization in white oaks (Quercus spp.) in California and Europe. Molecular Ecology 15: 4085-4093.

Hale, M. E. Jr. (1956a) Chemical strains of the lichen Parmelia furfuracea. American Fournal of Botany 43: 456-459.

Hale, M. E. Jr. (1956b) Chemical strains of the Parmelia conspersa-stenophylla group in south central United States. Bulletin of the Torrey Botanical Club 83: 218-220.

Hale, M. E. Jr. (1963) Populations of chemical strains in the lichen Cetraria ciliaris. Brittonia 15: 126-133.

Heinken, T. (1999) Dispersal patterns of terricolous lichens by thallus fragments. Lichenologist 31: 603-612.

Hewitt, G. (2000) The genetic legacy of the Quaternary ice ages. Nature 405: 907-913.

Hewitt, G. M. (1996) Some genetic consequences of ice ages, and their role in divergence and speciation. Biological Fournal of the Linnean Society 58: 247-276.
Hewitt, G. M. (1999) Post-glacial re-colonization of European biota. Biological fournal of the Linnean Society 68: 87-112.

Hey, J., Won, Y. J., Sivasundar, A., Nielsen, R. \& Markert, J. A. (2004) Using nuclear haplotypes with microsatellites to study gene flow between recently separated Cichlid species. Molecular Ecology 13: 909-919.

Högberg, N., Kroken, S., Thor, G. \& Taylor, J. W. (2002) Reproductive mode and genetic variation suggest a North American origin of European Letharia vulpina. Molecular Ecology 11: 1191-1196.

Honegger, R. \& Zippler, U. (2007) Mating systems in representatives of Parmeliaceae, Ramalinaceae and Physciaceae (Lecanoromycetes, lichen-forming ascomycetes). Mycological Research 111: 424-432.

Honegger, R., Zippler, U., Gansner, H. \& Scherrer, S. (2004a) Mating systems in the genus Xanthoria (lichen-forming ascomycetes). Mycological Research 108: $480-488$.

Honegger, R., Zippler, U., Scherrer, S. \& Dyer, P. S. $(2004 b)$ Genetic diversity in Xanthoria parietina (L.) Th. Fr. (lichen-forming ascomycete) from worldwide locations. Lichenologist 36: 381-390.

Jarne, P. \& Lagoda, P. J. L. (1996) Microsatellites, from molecules to populations and back. Trends in Ecology and Evolution 11: 424-429.

Joost, S., Bonin, A., Bruford, M. W., Despres, L., Conord, C., Erhardt, G. \& Taberlet, P. (2007a) A spatial analysis method (SAM) to detect candidate loci for selection: towards a landscape genomics approach to adaptation. Molecular Ecology 16: 3955-3969.

Joost, S., Negrini, R., Milanesi, E., Pellecchia, M. \& Marsan, P. A. (2007b) Detecting footprints of selection in Ovis aries by a spatial analysis approach. Italian Fournal of Animal Science 6: 171-173.

Jump, A. S., Hunt, J. M., Martinez-Izquierdo, J. A. \& Penuelas, J. (2006) Natural selection and climate change: temperature-linked spatial and temporal trends in gene frequency in Fagus sylvatica. Molecular Ecology 15: 3469-3480.

Kosman, E. \& Leonard, K. J. (2007) Conceptual analysis of methods applied to assessment of diversity within and distance between populations with asexual or mixed mode of reproduction. New Phytologist 174: 683-696.

Kroken, S. \& Taylor, J. W. (2000) Phylogenetic species, reproductive mode, and specificity of the green alga Trebouxia forming lichens with the fungal genus Letharia. Bryologist 103: 645-660.

Kroken, S. \& Taylor, J. W. (2001a) A gene genealogical approach to recognize phylogenetic species boundaries in the lichenized fungus Letharia. Mycologia 93: $38-53$.

Kroken, S. \& Taylor, J. W. (2001b) Outcrossing and recombination in the lichenized fungus Letharia. Fungal Genetics and Biology 34: 83-92.

Lättman, H., Lindblom, L., Mattsson, J. E., Milberg, P., Skage, M. \& Ekman, S. (2009) Estimating the dispersal capacity of the rare lichen Cliostomum corrugatum. Biological Conservation 142: 1870-1878. 
Lindblom, L. \& Ekman, S. (2006) Genetic variation and population differentiation in the lichen-forming ascomycete Xanthoria parietina on the island Storfosna, central Norway. Molecular Ecology 15: 1545-1559.

Lindblom, L. \& Ekman, S. (2007) New evidence corroborates population differentiation in Xanthoria parietina. Lichenologist 39: 259-271.

Lorentsson, S. \& Mattsson, J. E. (1999) New reports of soredia dispersed by ants, Formica cunicularia. Lichenologist 31: 204-207.

Loveless, M. D. \& Hamrick, J. L. (1984) Ecological determinants of genetic structure in plant populations. Annual Review of Ecology and Systematics 15: 65-95.

Lücking, R., Papong, K., Thammathaworn, A. \& Boonpragob, K. (2008) Historical biogeography and phenotype-phylogeny of Chroodiscus (lichenized Ascomycota: Ostropales: Graphidaceae). Fournal of Biogeography 35: 2311-2327.

Manel, S., Schwartz, M. K., Luikart, G. \& Taberlet, P. (2003) Landscape genetics: combining landscape ecology and population genetics. Trends in Ecology and Evolution 18: 189-197.

Mattsson, J. E., Hansson, A.-C. \& Lindblom, L. (2009) Genetic variation in relation to substratum preferences of Hypogymnia physodes. Lichenologist 41: 547-555.

Meudt, H. M. \& Clarke, A. C. (2007) Almost forgotten or latest practice? AFLP applications, analyses and advances. Trends in Plant Science 12: 106-117.

Moritz, C. (1994) Defining 'evolutionary significant units' for conservation. Trends in Ecology and Evolution 9: 373-375.

Moritz, C. (2002) Strategies to protect biological diversity and the evolutionary processes that sustain it. Systematic Biology 51: 238-254.

Mueller, U. G. \& Wolfenbarger, L. L. (1999) AFLP genotyping and fingerprinting. Trends in Ecology \& Evolution 14: 389-394.

Murtagh, G. J., Dyer, P. S., McClure, P. C. \& Crittenden, P. D. (1999) Use of randomly amplified polymorphic DNA markers as a tool to study variation in lichen-forming fungi. Lichenologist 31: 257-267.

Murtagh, G. J., Dyer, P. S. \& Crittenden, P. D. (2000) Reproductive systems - sex and the single lichen. Nature 404: 564-564.

Myllys, L., Högnabba, F., Lohtander, K., Thell, A., Stenroos, S. \& Hyvonen, J. (2005) Phylogenetic relationships of Stereocaulaceae based on simultaneous analysis of beta-tubulin, GAPDH and SSU rDNA sequences. Taxon 54: 605-618.

Nash, T. H. \& Zavada, M. (1977) Population studies among Sonoran desert species of Parmelia subg. Xanthoparmelia (Parmeliaceae). American fournal of Botany 64: 664-669.

Nei, M. (1978) Estimation of average heterozygosity and genetic distance from a small number of individuals. Genetics 89: 583-590.

Nelsen, M. P. \& Gargas, A. (2008) Dissociation and horizontal transmission of codispersing lichen symbionts in the genus Lepraria (Lecanorales: Stereocaulaceae). New Phytologist 177: 264-275.

O’Donnell, K. \& Cigelnik, E. (1997) Two divergent intragenomic rDNA ITS2 types within a monophyletic lineage of the fungus Fusarium are nonorthologous. Molecular Phylogenetics and Evolution 7: 103-116.

O’Donnell, K., Cigelnik, E. \& Nirenberg, H. I. (1998) Molecular systematics and phylogeography of the Gibberella fujikuroi species complex. Mycologia 90: 465-493.

Opanowicz, M. \& Grube, M. (2004) Photobiont genetic variation in Flavocetraria nivalis from Poland (Parmeliaceae, lichenized Ascomycota). Lichenologist 36: 125-131.

Paetkau, D., Slade, R., Burden, M. \& Estoup, A. (2004) Genetic assignment methods for the direct, realtime estimation of migration rate: a simulationbased exploration of accuracy and power Molecular Ecology 13: 55-65.

Palice, Z. \& Printzen, C. (2004) Genetic variability in tropical and temperate populations of Trapeliopsis glaucolepidea: evidence against long-range dispersal in a lichen with disjunct distribution. Mycotaxon 90: 43-54.

Parker, P. G., Snow, A. A., Schug, M. D., Booton, G. C. \& Fuerst, P. A. (1998) What molecules can tell us about populations: choosing and using a molecular marker. Ecology 79: 361-382.

Piercey-Normore, M. D. (2004) Selection of algal genotypes by three species of lichen fungi in the genus Cladonia. Canadian fournal of Botany 82: 947-961.

Piercey-Normore, M. D. (2006a) The lichen-forming ascomycete Evernia mesomorpha associates with multiple genotypes of Trebouxia jamesii. New Phytologist 169: 331-344.

Piercey-Normore, M. D. (2006b) Lichens from the Hudson Bay lowlands: diversity in the southeastern peatlands of Wapusk National Park, Manitoba. Canadian fournal of Botany 84: 1781-1793.

Piercey-Normore, M. D. \& DePriest, P. T. (2001) Algal switching among lichen symbioses. American fournal of Botany 88: 1490-1498.

Printzen, C. (2002) Fungal specific primers for PCRamplification of mitochondrial LSU in lichens. Molecular Ecology Notes 2: 130-132.

Printzen, C. \& Ekman, S. (2002) Genetic variability and its geographical distribution in the widely disjunct Cavernularia hultenii. Lichenologist 34: 101-111.

Printzen, C. \& Ekman, S. (2003) Local population subdivision in the lichen Cladonia subcervicornis as revealed by mitochondrial cytochrome oxidase subunit 1 intron sequences. Mycologia 95: 399-406.

Printzen, C., Ekman, S. \& Tønsberg, T. (2003) Phylogeography of Cavernularia hultenii: evidence of slow genetic drift in a widely disjunct lichen. Molecular Ecology 12: 1473-1486.

Printzen, C., Lumbsch, H. T., Schmitt, I. \& Feige, G. B. (1999) A study on the genetic variability of Biatora helvola using RAPD markers. Lichenologist 31: 491-499. 
Pritchard, J., Stephens, M. \& Donnelly, P. (2000) Inference of population structure using multilocus genotype data. Genetics 155: 945-959.

Robertson, J. \& Piercey-Normore, M. D. (2007) Gene flow in symbionts of Cladonia arbuscula. Lichenologist 39: 69-82.

Scheidegger, C., Clerc, P., Dietrich, M., Frei, M., Groner, U., Keller, C., Roth, I., Stofer, S. \& Vust, M. (2002) Rote Liste der gefährdeten Arten der Schweiz: Baum- und erdbewohnende Flechten. Bern: BUWAL.

Scheidegger, C. \& Werth, S. (2010) Conservation strategies for lichens: insights from population biology. Fungal Biology Reviews. (In press).

Scherrer, S. \& Honegger, R. (2003) Inter- and intraspecific variation of homologous hydrophobin $(\mathrm{H} 1)$ gene sequences among Xanthoria spp. (lichenforming ascomycetes). New Phytologist 158: 375-389.

Scherrer, S., Zippler, U. \& Honegger, R. (2005) Characterisation of the mating-type locus in the genus Xanthoria (lichen-forming ascomycetes, lecanoromycetes). Fungal Genetics and Biology 42: 976-988.

Sérusiaux, E. (1989) Liste rouge des macrolichens dans la Communaute Europeenne. Liege: Centre de Recherches sur les Lichens, Departement de Botanique, Sart-Tilman, 4000 Liege, Belgique.

Seymour, F. A., Crittenden, P. D., Dickinson, M. J., Paoletti, M., Montiel, D., Cho, L. \& Dyer, P. S. (2005a) Breeding systems in the lichen-forming fungal genus Cladonia. Fungal Genetics and Biology 42: 554-563.

Seymour, F. A., Crittenden, P. D. \& Dyer, P. S. (2005b) Sex in the extremes: lichen-forming fungi. Mycologist 19: 51-58.

Snäll, T., Pennanen, J., Kivistö, L. \& Hanski, I. (2005) Modelling epiphyte metapopulation dynamics in a dynamic forest landscape. Oikos 109: 209-222.

Stocker-Wörgötter, E., Elix, J. A. \& Grube, M. (2004) Secondary chemistry of lichen-forming fungi: chemosyndromic variation and DNA-analyses of cultures and chemotypes in the Ramalina farinacea complex. Bryologist 107: 152-162.

Stoddart, J. A. \& Taylor, J. F. (1988) Genotypic diversity - estimation and prediction in samples. Genetics 118: $705-711$.

Taberlet, P., Fumagalli, L., Wust-Saucy, A. G. \& Cosson, J. F. (1998) Comparative phylogeography and postglacial colonization routes in Europe. Molecular Ecology 7: 453-464.

Thor, G. (1998) Red-listed lichens in Sweden: habitats, threats, protection, and indicator value in boreal coniferous forests. Biodiversity and Conservation 7: 59-72.

Tønsberg, T., Gauslaa, Y., Haugan, R., Holien, H. \& Timdal, E. (1996) The threatened macrolichens of Norway. Sommerfeltia 23: 1-258.

Vasemägi, A., Nilsson, J. \& Primmer, C. R. (2005) Expressed sequence tag-linked microsatellites as a source of gene-associated polymorphisms for detecting signatures of divergent selection in
Atlantic salmon (Salmo salar L.). Molecular Biology and Evolution 22: 1067-1076.

Wagner, H. H., Holderegger, R., Werth, S., Gugerli, F., Hoebee, S. E. \& Scheidegger, C. (2005) Variogram analysis of the spatial genetic structure of continuous populations using multilocus microsatellite data. Genetics 169: 1739-1752.

Wagner, H. H., Werth, S., Kalwij, J. M., Bolli, J. C. \& Scheidegger, C. (2006) Modelling forest recolonization by an epiphytic lichen using a landscape genetic approach. Landscape Ecology 21: 849-865.

Walser, J. C. (2004) Molecular evidence for limited dispersal of vegetative propagules in the epiphytic lichen Lobaria pulmonaria. American fournal of Botany 91: 1273-1276.

Walser, J. C., Gugerli, F., Holderegger, R., Kuonen, D. \& Scheidegger, C. (2004) Recombination and clonal propagation in different populations of the lichen Lobaria pulmonaria. Heredity 93: 322-329.

Walser, J. C., Holderegger, R., Gugerli, F., Hoebee, S. E. \& Scheidegger, C. (2005) Microsatellites reveal regional population differentiation and isolation in Lobaria pulmonaria, an epiphytic lichen. Molecular Ecology 14: 457-467.

Walser, J. C., Sperisen, C., Soliva, M. \& Scheidegger, C. (2003) Fungus-specific microsatellite primers of lichens: application for the assessment of genetic variation on different spatial scales in Lobaria pulmonaria. Fungal Genetics and Biology 40: 72-82.

Weising, K., Nybom, H., Wolff, K. \& Kahl, G. (2005) DNA Fingerprinting in Plants - Principles, Methods, and Applications. Boca Raton: Taylor \& Francis.

Werth, S. \& Sork, V. L. (2008) Local genetic structure in a North American epiphytic lichen, Ramalina menziesii (Ramalinaceae). American fournal of Botany 95: 568-576.

Werth, S., Wagner, H. H., Gugerli, F., Holderegger, R., Csencsics, D., Kalwij, J. M. \& Scheidegger, C. (2006a) Quantifying dispersal and establishment limitation in a population of an epiphytic lichen. Ecology 87: 2037-2046.

Werth, S., Wagner, H. H., Holderegger, R., Kalwij, J. M. \& Scheidegger, C. (2006b) Effect of disturbances on the genetic diversity of an old-forest associated lichen. Molecular Ecology 15: 911-921.

Werth, S., Gugerli, F., Holderegger, R., Wagner, H. H., Csencsics, D. \& Scheidegger, C. (2007) Landscapelevel gene flow in Lobaria pulmonaria, an epiphytic lichen. Molecular Ecology 16: 2807-2815.

Wirth, V., Schöller, H., Scholz, P., Ernst, G., Feuerer, T., Gnüchtel, A., Hauck, M., Jacobsen, P., John, V. \& Litterski, B. (1996) Rote Liste der Flechten (Lichenes) der Bundesrepublik Deutschland. Schriftenreihe für Vegetationskunde 28: 307-368.

Yahr, R., Vilgalys, R. \& DePriest, P. T. (2006) Geographic variation in algal partners of Cladonia subtenuis (Cladoniaceae) highlights the dynamic nature of a lichen symbiosis. New Phytologist 171: 847-860.

Zhang, D. X. \& Hewitt, G. M. (2003) Nuclear DNA analyses in genetic studies of populations: practice, problems and prospects. Molecular Ecology 12: 563-584. 
Zoller, S., Lutzoni, F. \& Scheidegger, C. (1999a) Genetic variation within and among populations of the threatened lichen Lobaria pulmonaria in Switzerland and implications for its conservation. Molecular Ecology 8: 2049-2059.
Zoller, S., Scheidegger, C. \& Sperisen, C. (1999b) PCR primers for the amplification of mitochondrial small subunit ribosomal DNA of lichen-forming ascomycetes. Lichenologist 31: 511-516.

Accepted for publication 20 fanuary 2010

\section{Appendix 1: Glossary}

AFLP. Amplified fragment length polymorphism. A dominant DNA marker based on the fragment length of restricted PCR products, used for applications including fingerprinting to discriminate among individuals and phylogeography.

Chemotype. The assemblage of secondary metabolites, typically phenolic compounds and/or fatty acids, of a given lichen thallus.

Heterothallic. Self-sterile. Heterothallic mycobionts contain only a single mating type gene (either matK1 or matK2), and to recombine, they need a partner containing the complementary mating type gene.

Homothallic. Self-fertile. Homothallic mycobionts contain both matK1 and matK2 and thus are able to recombine without a partner, which leads to an offspring genotype identical to that of the parent. In addition to selfing, outcrossing may occur.

ISSR. Inter simple sequence repeats, a fingerprint type amplifying the regions between SSR loci.

Landscape genetics. The study of gene movement across landscapes, accomplished by a combination of landscape ecology and population genetics methods (Manel et al. 2003).

PCR-RFLP. Restriction digest of PCR-amplified DNA, revealing DNA-nucleotide polymorphism.

Phylogeography. The distribution of genetic diversity across (a large part of) the world range of a taxon, typically used e.g. to infer the location of glacial refugia and post-glacial immigration routes.

RAPD. Randomly amplified polymorphic DNA, a dominant marker type used for DNA fingerprinting, today tending to be abandoned owing to lacking repeatability of the fingerprints.

RFLP. Restriction digest of genomic DNA leading to a fingerprint.

SNP. Single nucleotide polymorphism marker, gained from studying DNA sequence variation, a marker type widely used in phylogenetics and population genetics.

SSR. Simple sequence repeat, a marker type where a nucleotide motif is tandemly repeated [e.g., $(\mathrm{GTC})_{\mathrm{n}}$ ], the number of repeats creating the measured fragment length polymorphism. Microsatellites are SSR loci with short repeat units, up to $6 \mathrm{bp}$, whereas minisatellites contain longer repeat units. 


\section{Appendix 2. Statistics that could be reported in future studies to facilitate compa- rability among studies}

\begin{tabular}{lcc}
\hline All markers & DNA sequences & Microsatellites \\
\hline $\begin{array}{c}\text { Analysis of molecular variance } \\
\text { (partitioning of variance, e.g. } \\
\text { among populations and regions), } \\
\text { with } \Phi_{\mathrm{ST}}\end{array}$ & $\begin{array}{c}\text { Nucleotide diversity } \pi \text { (within } \\
\text { populations and total) }\end{array}$ & $\begin{array}{c}\text { Nei's unbiased gene diversity } \\
\text { (within populations) (Nei 1978) }\end{array}$ \\
$\begin{array}{l}\text { Pairwise } F_{\mathrm{ST}} \text { values and their } \\
\text { significance (e.g. in an appendix) }\end{array}$ & $\begin{array}{c}\text { Number of haplotypes (for each } \\
\text { locus separately and averaged } \\
\text { across loci; within populations } \\
\text { and total) }\end{array}$ & $\begin{array}{c}\text { Number of alleles (for each locus } \\
\text { separately and averaged across } \\
\text { loci; within populations and } \\
\text { total) }\end{array}$ \\
$\begin{array}{l}\text { Number and percentage of } \\
\text { multilocus genotypes, } \mathrm{M} \text { (within } \\
\text { population; number of multilocus } \\
\text { genotypes / sample size) }\end{array}$ & $\begin{array}{c}\text { Number of polymorphic sites } \\
\text { (within populations) }\end{array}$ & $\begin{array}{c}\text { Mean number of alleles across } \\
\text { markers (within populations) }\end{array}$ \\
\hline
\end{tabular}

